ing, (The Macmillan Company) should be in all libraries.

While speaking of magazines, may we suggest that such articles appearing recently in the Journal as Dr. Lucas' "Normal Development of the Child," and Dr. Caroline Hedger's, which give so clearly and forcibly the present concept of positive health might easily be made required reading and form the basis of helpful class discussion. Reprints of these are available through the office of the National League of Nursing Education, 370 Seventh Avenue, New York.

It is probably not generally known that the library of the N. O. P. H. N. has recently been combined with the libraries of the other health organizations forming the coalition of health agencies at 370 Seventh Avenue. This library service, now known' as the National Health Library, 370 Seventh Avenue, New York, is at the disposal of all interested in this subject. The library, on request, will furnish reading lists on all public health subjects, such as Social Hygiene, Mental Hygiene, Tuberculosis and Public Health Nursing, and will lend packages of pamphlets on these subjects. The librarian will be glad to hear from any superintendents of training schools who would like to make use of this service.

The National Organization for Public Health Nursing issues "every little while" a list of available current pamphlets. The organization also publishes through its Committee on Education, a statement on the Scope, Preparation, and Opportunities for Public Health Nursing, which presents the subject briefly and concisely. This pamphlet also gives a list of postgraduate courses in public bealth nursing. These and other pamphlets will be sent on request from any one interested.

If all, or most, of these suggestions are carried out, no student should graduate from her training without at least a sufficient knowledge of this subject to guide her in the choice of work.

\title{
MOUNTAIN CHILDREN IN KENTUCKY
}

By Lucy E. Halbert

Hindman Settlement Nurse

$\prod_{\text {fully hospitable they are. The }}^{\text {HE mountain people! Wonder- }}$ children are brave,-very, very brave. An inborn bravery it is. There is a mighty future before these young folks of the mountains, grasping the opportunity of an education and zealously putting into execution their long latent talents. To be a health worker among them is, indeed, a privilege.

My early childhood was spent at the foot of the Kentucky mountains along the Ohio River. The mountains al- ways have appealed to me, the beauty of the early morning mist, the splendor of the sunrise, the sunset, and the moon rising above the lofty trees. But I scarcely knew about the inhabitants.

Many years have passed since then, and now I am really here in the very tops of the hills. Pioneer workers have come before me and made the path easy. Still, there is much to be done. But the people are coöperative. They gladly receive the health lessons brought to them. They want health 
more than anything else, that their little ones may be physically and mentally strong.

I would again mention the bravery of the children. It is remarkable the way a twelve-year-old boy faces and endures an anaesthetic and an operation without a murmur or a struggle; as it is for a little one to have his fingers shot off and then walk home, a long distance, without a tear, that his mother might not be badly frightened. A little crippled girl, with a leg ready for the surgeon's knife, waiting day after day, and week after week, for her opportunity to go away for an operation; and, waiting, to ever wear a smile and to show a tenderness and thoughtfulness for the eight younger children at home,- - this is another sample of what we find in the mountains. It is not an easy matter to get such a case as this to the railroad; a spring wagon, with a spring and mattress in it, would prove too severe a carriage, so this little girl will be taken on a stretcher for a distance of about twenty miles over the mountains, and by night, to avoid the hot sun beating down upon her. If the bearers should be soldier boys, then the journey would be less wearisome than if made by the mountain men who have never been trained to keep in step.

With one nurse to a county (some counties haven't even the one), the health work progresses but slowly. More workers are needed, and more will come, for God works surely. If there be a nurse who has felt a desire to work in the rural district, but hesitates to sever the city's ties, she is missing a great joy in life.

Our readers will be interested to know that the Hindman Settlement School is the pioneer Settlement School of the Kentucky mountains. It was founded in 1902 by May Stone and Katherine Pettit after three summers of social work in three different counties, living in tents and conducting classes and clubs for young and old. One of these counties was Knott County, where the people held mass meetings and besought the two women to stay with them and start a school. Thus the Hindman Settlement School was started which now combines academic and industrial education with many forms of social service. A district nurse, a school nurse, and a well equipped hospital are among these. Requests and offers of land soon came from other mountain counties to start similar schools. "The History of the Pine Mountain Settlement School," a delightful illustrated pamphlet published by the Settlement gives a very moving picture of its history and establishment. William Creech, a farmer, blacksmith, thinker, and educator, saw his county losing all the homely and beautiful knowledge of the past, with no opportunity for acquiring the knowledge of the present day, and wrote these notable words,

There being lots of whiskey and wickedness in the community where my grandehildren must be raised was a very serious thing for me to think about.

But this sturdy citizen did more than think and dream-these were his brave conclusions:

I don't look after wealth for them. I look after the prosperity of our nation. I want all young-uns taught to serve the livin' God. Of course, they won't all do that, but they can have good and evil laid before them and they can choose which they will. I have heart and cravin' that our people may grow better. 
I have deeded my land to the Pine Mountain Settlement School to be used for school purposes as long as the Constitution of the United States stands. Hopin' it may make a bright and intelligent people after I am dead and gone.

Fortunately, Uncle William, as he was affectionately called, had seen the work of Miss Pettit and Miss de Long at the Hindman Settlement, and finding their ideas of education were as his own, he gave all the land he owned, one hundred and thirty-six acres, to found the Pine Mountain Settlement School. Other acres have since been added and the Settlement, incorporated in 1913, now owns over four hundred acres of farm and timber lands, with buildings and equipment for its varied activities, and with a settlement "family" of over one hundred. Extensive work has begun and on "the 'fur' side" of Pine Mountain the Line Fork Settlement is already an active branch with resident industrial workers and a public health nurse who writes in one of their little pamphlets a charming account of her work as a "fotched-on nurse."

After much discussing of the relative values of a separate bed with a firm mattress and those of a big feather bed shared with the mother, for a new baby, the nurse was only able to get the mother of the latest newcomer "up 'Possum Way" to "low a separate bed might be a sight handy in takin' keer of a young un." But when the pretty cretonne, which the nurse had ordered, finally arrived, the young mother was quite won over to the merits of a separate bed. She could then hardly wait until a suitable box could be gotten for it, she was so eager to see it covered with the pretty cloth, to have the mattress made, and to see her "young un tucked away in it." Finally, just that was accomplished, while a proud "pappy" and the nurse looked on. But the old grand-pap, who sat "jest a whittlin'" by the open fire, appeared disgusted. He was forbearing at first, but after standing it as long as he could, he said, "I been a livin' over eighty years, and hain't never seed a poor young un in sech a fix before. You hain't a aimin'," said he, "to let the poor leetle bit a thing stay in that box by hisself all night, air ye?"

Many of us have read and enjoyed the articles called Quare Women by Lucy Furman which have been appearing in recent numbers of the Atlantic Monthly. Very true pictures, our friends, the nurses at the Settlement School, tell us. And Ann Cobb's Kinfolk poems also charmingly depict mountain characters and manners as they are seen and loved by the nurses and other workers. One of the "Notes" of the Pine Mountain Settlement School gives a delightful account of the efforts made to preserve the ballads that have been cherished in these remote places since the first settlers brought them from their English homes, with quaint additions and new folk songs inspired by their peculiar environment. One, never included in any printed collection, is the "courtin' song" of the pioneer oneroomed house where young lovers could only secure privacy for themselves by. waiting until sleep overtook the family and a space in front of the fire gave the young folk a precarious seclusion.

A gentleman came to our house, he would not tell his name;

I know he came a-courtin', although he were ashamed,

Oh, although he were ashamed.

He moved his cheer up to my side, his fancy pleased me well,

I thought the sperrit moved him some handsome tale to tell.

Oh, thar he sot the livelong night, and never a word did say;

With many a sigh and bitter groan he ofttimes wished for day.

But this is a nursing journal! No more. 